\title{
Management of Partnerships between Vocational High Schools with Business and Industry to Improve Graduate Competencies
}

\author{
Beni Habibi ${ }^{1}$, Ira Maya Hapsari ${ }^{2}$ \\ Program Studi Pendidikan Ekonomi FKIP Universitas Pancasakti Tegal ${ }^{1}$, Program Studi \\ Manajemen FEB Universitas Pancasakti Tegal ${ }^{2}$ \\ \{benihabibi@upstegal.ac.id ${ }^{1}$, mayahabibie77@gmail.com²
}

\begin{abstract}
This study aims to obtain an empirical picture of the partnership between SMK with DUDI in strategic planning, implementation, effectiveness, results and benefits of partnership cooperation in school development. This research was located at SMK Negeri 2 Kota Tegal. This research approach used qualitative naturalistic, descriptive methods and case studies, and research techniques used interviews, observation and documentation study. The results of this study indicate that: (1) The management of the partnership between the Business World and the Industrial World at SMK Negeri 2 Tegal City. (2) Planning for cooperative relations through the school relations program with the business world / industrial world so far implemented at SMK Negeri 2 Tegal City, namely scholarships, internship, training, industrial visits, and alumni recruitment. (3) The implementation of establishing school cooperation includes: Procedures for implementing partnerships with the business / industrial world at SMK Negeri 2 Tegal City, (4) Evaluation in the implementation of school cooperation. It is hoped that the business / industrial world will pay more attention to the interests of students and schools.
\end{abstract}

Keywords: Partnership Management, SMK, DUDI, Competence Graduates

\section{Introduction}

Entering the world of industry and technology, the world of education in Indonesia is facing increasingly difficult and complex challenges. The development of the world of education is currently entering an era marked by the incessant invasion of technology and industrial innovation, thus demanding an adjustment of the education system in line with the demands of the world of work. The role of the education sector in preparing these resources must not be neglected. Educational programs must be oriented towards the needs of the job market. Likewise, the products produced by the business world are the consumption of the wider community. Thus the education and training process will give meaning to the achievement of national education goals. Lestari and Pardimin (2019: 102).

Education is the most strategic sector in sustainable national development, this is because improving the quality of human beings who are the subject of development can only be achieved through education. In a global perspective, education plays a role in: 1) personal 
development, 2) employability or work skills development, 3) citizenship development, and 4) cultural transmission and transformation (transsmision and transformation). culture). The education that is most suitable to face the challenges of globalization is education that is oriented to the industrial world, so that vocational schools in the learning process must be able to make appropriate learning approaches and according to the needs of the industrial world. Vocational education is part of the national education system which aims to prepare students to be ready to work in certain fields according to their fields of expertise. Vocational High Schools and Vocational Madrasah Aliyah (SMK / MAK) are forms of vocational education at the secondary level that produce graduates with special expertise in business and industry. (Arifin, 2012: 61).

SMK graduates are expected to have the ability to live independently and be able to develop knowledge and expertise in society. The intended objective is regulated in Government Regulation Number 19 Year 2005 Article 26 of the competency standards for graduates in vocational secondary education units. In this regulation, it is explained that the competence of graduates in vocational secondary education units aims to improve intelligence, knowledge, personality, noble character, and skills to live independently and follow further education in accordance with their vocational studies (Setiawan, 2016: 26). In addition, to optimize and carry out quality assurance and quality of graduates, vocational schools have as early as possible brought students closer to the world of work and the world of industry through several programs that have been arranged in the learning system for a certain period. However, with regard to quality assurance of these graduates, vocational schools face many obstacles and challenges that are often a tough task for schools. Some of the obstacles that are often faced by vocational schools include the competence gap between vocational school graduates and the competencies that are currently needed by the world of work.

Suryadi (2010: 5) states that vocational education in schools has caused structural problems that lead to a lack of relevance to employment. The development of the current study program has not changed because educational devices are formed legally and formally, which can limit the creativity space of program managers and appear to "avoid" change. On the other hand, the business world continues to change with the influence of technological developments and innovation, even the business world is currently keeping up with the demands of the times with the role of information technology which is so fast that it makes the business world very fast in responding to market demands.

One of the efforts to improve the quality or quality of vocational education graduates is the establishment of a link and match policy, where schools, especially vocational secondary education, make it possible to collaborate with the Business World and the Industrial World in fostering and developing the potential of students in the field. The synergistic relationship between schools and the world of business and the world of industry is a very helpful condition in an effort to create a truly effective process for students. Provision of skills for students is the main thing that must be a school program and the world of business and industry. The collaboration carried out by Vocational High Schools with the Business World and the Industrial World is a learning and business strategy designed to enhance cooperation that can benefit both parties. This pattern of cooperation must be carried out by schools with a pick-up pattern, visiting the Industry to seek competency needs that can encourage Industrial progress in terms of minimum human resource capabilities for the Industry operator level, which then Industry will grow and develop through the addition of competencies, and schools can guarantee the training pattern, the available equipment and the teachers do have the ability of Shari and Ma'arif (2017: 2). Applicative expertise is provision related to the needs of society and industry. If school institutions and DUDI provide skills training according to 
community needs, of course school graduates can be maximally absorbed by DUDI. This condition is what we really expect from the education and learning process in vocational schools.

The principle of industrial cooperation between schools and the world of work ultimately has the aim of accelerating the adjustment time for Vocational School graduates to enter the world of work which will ultimately improve the quality of vocational high schools. A great deal of attention to vocational education is related to the principles of vocational education, as identified by Barlow (Murniati and Usman 2009: 20), namely: (1) Vocational education is a rational concern for labor, industrial education, agriculture and government assistance, economic needs is a national framework of vocational education; (2) Vocational education maintains public defense and promotes public welfare; (3) Vocational education prepares adolescents and adults, is the responsibility of government schools, democratization of education where the government shows a good industry for vocational education needs in the government school education industry; (4) Vocational education requires a basic education; (5) Vocational education is planned and led in close collaboration with employers and industry; (6) Vocational education provides valuable skills and knowledge in the labor market; (7) Vocational education provides further education for adolescents and adults.

Partnerships between vocational education and the private sector should receive support from the government, one of which is financial support as a strategy to achieve success in management and revitalization in a country Ixtiarto and Sutrisno (2016: 59). It is believed that vocational education collaborative partnerships will make a difference. Adequate vocational education ensures the production of a skilled workforce who have the knowledge and attitudes required for a professional career. Observing the explanation of these facts and problems, it is best if efforts are made to continuously strive for a systematic, concrete and measured program of educational institutions to develop an adequate educational model so as to produce graduates who meet qualifications to enter the business world and the industrial world. According to Kuswana (2013: 34 ) that a person is required to have the ability to cooperate and deal with other people, on the basis of a combination of abilities to work together and communicate. So that vocational high schools should develop the ability to collaborate and communicate with institutions, in this case the business world and the industrial world.

In getting to know the success of partnership development, measurable indicators are needed. In determining indicators, the principles of indicators should be understood, namely: specific, measurable, achievable, realistic and timely. As stated by Sufyarma in Rukmana (2006: 21) education success indicators must be supported by the quality of the process in achieving goals which have the characteristics: a) The study program is well programmed, b) the curriculum must be relevant to the job market, c) the availability of adequate staff, d ) good and ready-to-use educational equipment, e) sufficient funds for the learning process, f) well managed through a lean organization. Indicators of the success of vocational high schools in establishing partnerships with the business world and industry are shown: a) the formation of a partnership cooperation team with the business and industrial world, b) the implementation of exploration of cooperation with related partners to obtain input before program implementation, c) the realization of a cooperation contract as outlined in a memorandum of understanding with the partners, and d) the realization of various activities within the framework of the successful implementation of programs such as student exchanges, teachers, school principals, and apprenticeships in an effort to add insight and competence. (Ministry of National Education, 2009: 64) Thus the implementation of educational partnerships will be effective, shown by the success in achieving the indicators that have been determined in the policy in establishing cooperation, such as improving the 
quality of learning, the quality of student success, the harmony and relevance of the curriculum to the world of work and the increasing level of absorption. graduates in the world of work. The objectives to be achieved in writing the results of this study are: 1). Describe the partnership management plan of SMK Negeri 2 Tegal City with the business world and the industrial world, 2) Describe the implementation of the partnership between SMK Negeri 2 Kota Tegaldeh with the business world and industrial world, 3) Describe the control of the implementation of the partnership between SMK Negeri 2 Tegal City with the business world and the industrial world

\section{Materials and Methods}

Vocational education is part of the education system that prepares someone to be better able to work in a group of jobs or one job field than in other fields of work. Thus, vocational / vocational education in the national education system is expected to be able to prepare and develop human resources who are capable of working professionally in their fields, as well as competitiveness in the world of work, especially in facing the demands of the global world to be able to compete with other countries. Vocational education that is tailored to the provision of employment opportunities is a very basic and essential need in the process of Indonesia's national development.

The high level of unemployment originating from graduates of SMK or vocational education generally arises because of a mismatch between the output of schools that cannot meet the needs of the business world and the ever-growing industrial world. Therefore, it is necessary to improve the competence of SMK graduates so that they are better prepared to enter the workforce The role of partnerships is needed to establish mutually beneficial cooperation in order to be able to produce graduates who have the appropriate competencies required by the business world and the industrial world.

\section{Types of research}

This type of research is descriptive research supported by qualitative data. According to Cooper and Schindler (2011: 149) descriptive research is a research study used to describe phenomena related to the subject or population to estimate the proportion of the population that has certain characteristics. The main purpose of descriptive research according to Neuman (2006: 30) is to get a detailed picture of a situation, as well as answer questions such as who, when, where, and how. The type of descriptive research was chosen because this study aims to describe things related to the management of school partnerships with the business world and the industrial world that are running in SMK Negeri 2 Tegal City. Miles \& Hubermann (1992: 15) add that research using qualitative data will produce data in the form of words and not a series of numbers. The data may have been collected in a variety of ways (observation, interview, digest, documents, tapes) and which is usually processed through recording, typing, editing, or transcribing. The research site is SMK Negeri 2 Tegal City with the time of the research being conducted in September-October 2019.

According to Sugiyono (2005: 62) data collection techniques are the most strategic steps in research, because the main purpose of research is to get data from sources. The techniques used in this research are interviewing, observation, and documentation study techniques. In this study, researchers used a combination of structured and unstructured interviews to obtain as much information as possible about the partnership management between SMK Negeri 2 
Tegal City and the business world and the industrial world and its impact on the competence of the graduates produced. Observations were made by observing and recording the management of partnerships between SMK Negeri2 Tegal City and the Business and Industrial World in terms of planning, organizing, implementing / directing and evaluating. Documentation studies collected include vision, mission, and school goals documents, SWOT analysis documents, RKS, RKJM, Organizational Structure, Team Decrees, meeting documents, MoU with the Business World and the Industrial World, minutes, activity reports, photographs and documents. evaluation of school partnerships with the world of business and the world of industry.

Research subjects The subjects of this study were the principal, the vice principal in the field of curriculum, public relations and industrial relations, the Coordinator of the Special Job Exchange (BKK), the Secretary of the Dual System Education Program (PSG), students and the Business and Industrial World Data processing techniques. data using techniques from Miles \& Hubermann (1992: 20) data processing stages which include (1) data selection; 2) data classification; and (3) compilation of data. After the data collected has been selected, it is then arranged systematically by entering into their respective discussion groups, after which analysis is carried out to get a picture that really matches what the purpose of writing was done.

Data validity Validation or data validity is done by using triangulation. According to Miles and Huberman in Prastowo (2012: 242) triangulation techniques can be divided into 3 types, namely: triangulation with sources; triangulation technique; and time triangulation. Data analysis techniques The data that has been obtained were analyzed using analysis techniques that refer to Miles and Huberman which include (1) data reduction; (2) data presentation / display; (3) verification or drawing conclusions.

\section{Results and Discussion}

From this research, it is found that the school relations program offered includes promotion of alumni, internship and products. The procedures for implementing partnerships with the Business World and the Industrial World at SMK Negeri 2 Tegal City, which started with the Deputy of Public Relations with BKK, made a plan for tracing activities and compiled a draft of graduation tracing and marketing of graduates, if the Principal did not approve the proposal, the proposal would be revised. Then Deputy Public Relations with BKK socialize to prospective graduates and fill out a form where data analysis is based on filling out the form, namely the classification of continuing to study or work. The Public Relations team together with BKK establish relationships with the Business World and the Industrial World with an interest in canakers / graduates through: Job fairs, visits, internet, or phone calls and then Waka Humas together with BKK compile a recruitment schedule after which coordinate with the Principal and Curriculum Deputy to match the agenda school activities and coordinating the implementation of recruitment. Then BKK sends students who pass the selection to the world of business and the world of industry and input student data that has been distributed. Lastly, evaluating graduate tracking and marketing activities.

From the findings above, it can be explained from the results of research at SMK Negeri 2 Tegal City regarding the management of school partnerships with the business world and the world in increasing the competence of graduates resulting in several research findings as follows: 
3.1 Partnership Management of SMK Negeri 2 Tegal City with the Business World and the Industrial World in Terms of Planning, Organizing, Implementing and Controlling / Evaluating Aspects in Improving the Competence of Graduates.

\section{a) Planning (Planning)}

The stages in planning in forging a partnership with the Business World and the Industrial World carried out by the management of SMK Negeri 2 Tegal City are: 1) Incorporating elements of school partnerships with the Business World and Industrial World into the vision, mission and goals of the school 2) Planning the partnership program contained in the school work plan (RKS) and the four-year medium term plan (RKJM) 3) Conducting an internal and external analysis of the school 4) Formulating a partnership management structure with the Business and Industrial World 5) Selection and sorting of the Business World and the Industrial World 6) Proposing for school partnerships with the world of business and the world of industry 7) Equip facilities for school collaboration with the world of business and the world of industry.

At this planning stage, various activities related to school partnerships with the DUDI world of business and industry that have been carried out before are evaluated to determine what steps to take next. This activity was carried out through discussion forums from the school management and brainstorming from the parties concerned such as teachers, employees, students and from DUDI. Forms of cooperation made by schools with the business world and the industrial world include synchronizing curricula, apprenticeship / internship programs, collaborating training programs and collaborating with graduate distribution programs. The cooperation carried out by the school is the main thing and becomes the school's main program in the field of public relations which is solely aimed at channeling students into the industrial world in accordance with their field of expertise.

The results of the above research are in line with the theory put forward by Abuzar. H. (2011) which states that SMK with the business world through link and match as a form of partnership can provide benefits. a) Students can directly see how the role of technology in the business world so that after graduating, it is no longer awkward to interact with technological processes in the business world. b) Motivating SMK students to be even better, in the sense that they can find new innovations because they have seen it firsthand. c) Able to improve the quality of SMK graduates because in the business world the most important thing is discipline so that they can continue to survive, for example the small things indicating that quality has begun to bloom in school is a commitment to time and learning discipline, work ethic, a culture of competition and achievement . d) It is easier to design a competency-based curriculum because it directly meets the demands of the business world. e) The form of labor recruitment will no longer be difficult. This means that SMK stakeholders can recommend high-achieving students to become workers.

The results of this study when compared with previous studies, the planning carried out by SMK Negeri 2 Tegal City to establish a partnership with DUDI can be categorized as mature, namely (1) determining the goals and mission of the school; (2) identify the goals the school wants to achieve; (3) setting short-term and long-term goals; (4) structuring current conditions logically, measurable and accurate; (5) compiling work guidelines that serve as collective guidelines; (6) making work implementation regulations; (7) compiling the target framework for each job position, it can be concluded that most of the planning steps of the partnership management carried out by SMK Negeri 2 Tegal City are in accordance with the indicators of success in the research grid, so it can be said to be good. 


\section{b) Organizing (Organizing)}

According to Terry in Hasibuan (2007: 122) states that organizing is an act of seeking effective behavioral relationships between people, so that they can work together efficiently and obtain personal satisfaction in carrying out certain tasks in certain environmental conditions to achieve goals or specific target. The organization that is carried out in school partnership activities with DUDI is to form a team or working group in charge of industrial relations and have their own main duties and functions. This is done so that management can work professionally and avoid multiple positions. The principal together with the deputy head, especially curriculum and public relations / industrial relations, form a working group (Pokja), namely the PKL / internship team and the BKK team. This team collaborates with divisions in the school and DUDI for the smooth running and implementation of cooperation.

Based on the documentation study obtained, the forms of organizing the collaboration include documents or archives in the form of a Decree on the Division of Tasks or the formation of a Pokja Team or committee, the organizational structure of the SMK partnership. If the results of the research from the organizing stage carried out at SMK Negeri 2 Tegal City are compared with the indicators of success in the research grid from the organizational aspect in the form of (1) details of all work that must be carried out by each individual in achieving goals; (2) distribution of workload; (3) procurement and development of work mechanisms, it can be concluded that most of the organizational steps of partnership management carried out in the Clinical Pharmacy Department of SMK Negeri 2 Tegal City are in accordance with the indicators of success in the research grid, so it can be said to be good.

\section{c) Actuating}

The implementation of the partnership between SMK Negeri 2 Tegal City with the business world and the industrial world is made an MoU which contains the contents according to the agreed field of cooperation, including curriculum synchronization, industrial visits, guest teachers, internships, vocational competency tests (UKK), OJT or productive teacher apprenticeships, equipment assistance practice, school funding and participants from industry, production units, certification and recruitment / placement of graduates. In fact, the placement of graduates in work is not in accordance with the competencies of students according to their fields.

From the results of research by Sri Utami (2010) it has been explained that in order for partnerships to be maximally established, the management of partnerships (cooperation) with the business world and the industrial world in Industrial Work Practices (Prakerin) must be in accordance with applicable procedures to equip students with competency skills. in accordance with the demands of national work standards. The school (SMK) has attempted to increase the partnership (cooperation) of schools with the world of business and the world of industry by involving all components related to the learning process, both internally and nonschool related institutions and channeling and placing workers according to their fields.

Based on the fact that some SMK graduates who have worked in industry are less able to adapt to the environment and infrastructure in the industry and have not graduated who work according to their competencies, so they cannot solve the problems being faced in the industry that are in line with their fields, even less precise in operating the facilities that should be controlled.

The results of this study, when compared with previous studies, still have shortcomings, namely the lack of training held by DUDI partners. The importance of training for vocational 
school students who are trained and educated by partners in accordance with the needs of partners in the field will certainly bring great benefits both to students, to schools and to DUDI itself. Because the partnership between SMK and DUDI is not just "there" a partnership between the school and the Industrial World but actually students can be channeled optimally according to the world of work that needs them. On the other hand, partners, in this case the industrial world, will also get the benefit, that the workforce they recruit will work well and professionally according to the partner's needs.

\section{d) Evaluation (Controlling)}

The evaluation of the achievements of the management of the collaboration that has been carried out between SMK Negeri 2 Tegal City with the business world and the industrial world is (1) Performing student aspirations, (2) Assessing the results of student presentations, (3) Evaluating reports of related teams or supervisors related to school partnerships and DUDI, (4) Harmonization or renewal of cooperation between the two parties. The evaluation was carried out using the brainstorming method in a meeting forum to produce conclusions from the results of the analysis. In addition, evaluation and assessment are also carried out through the following steps: (1) see whether the program contained in the $\mathrm{MoU}$ is running or not, this is done by looking at the results of monitoring. (2) if there is a deviation, coordination will be carried out with DUDI and deliberation for the common good. (3) if there is an excess because DUDI provides better grades, then the school will give a reward to the DUDI party (4) adjustments to the MoU on DUDI which has improved quality and cooperation.

\subsection{The Forms of Cooperation Carried Out by SMK Negeri 2 Tegal City with the Business World and the Industrial World}

The forms of school collaboration with DUDI at SMK Negeri 2 Tegal City include: (1) reviewing and adjusting the curriculum with DUDI; (2) implementation of apprenticeship / PKL for students (Prakerin); (3) implementation of apprenticeship / PKL for teachers; (4) manufacture of traditional preparations / products; (5) implementation of vocational competency examinations (UKK).

Through documentation studies, data was obtained that the forms of cooperation carried out at SMK Negeri 2 Tegal City with the business world and the industrial world so far are the Dual System Education program or industrial work practices, vocational competency tests (UKK) and the Special Job Exchange (BKK). ) which handles job vacancies for graduates and alumni. Industrial work practice (prakerin) activities are carried out in collaboration with several government agencies, private companies, and small and medium enterprises in the city of Tegal and its surroundings. Vocational competency testing activities are carried out by involving practitioners, namely pharmacists who happen to be several teachers at SMK Negeri 2 Tegal City acting as examiners and SMK Negeri 2 Tegal City acting as LSP (Professional Certification Institutions) in Tegal City.

Partnership activities between the Special Job Fair (BKK) at SMK Negeri 2 Tegal City with the business world and the industrial world that have been carried out include holding collaborations with alumni and companies through job fairs and information services which are expected to increase the absorption of graduates in the world of work. However, from the findings, it turns out that BKK in the services provided is limited to providing information related to job vacancies or internships in certain companies or industries. Have not studied in 
depth or made service programs that collaborate or recruit graduates with DUDI as stipulated in an agreement $(\mathrm{MoU})$.

\subsection{Factors supporting the partnership between SMK Negeri 2 Tegal City with the Business and Industry World.}

In building cooperation between SMK Negeri 2 Tegal City and DUDI, several supporting factors were found, namely: (1) the same vision and mission of the school and DUDI; (2) there are mutually beneficial interests of the school and DUDI. (3) the ability and support of the school committee; (4) availability of adequate facilities and infrastructure. The results of the documentation study showed that the school committee was involved in school collaboration with DUDI. This can be seen from the organizational structure formed in the collaboration, such as in a Team Decree or committee. During meetings or discussion forums related to school collaboration activities with DUDI, the committee is also involved. This is evidenced by the attendance list of meeting activities / meeting minutes. The facilities and infrastructure provided by the school are proven by photo documentation of the facilities at the school that support student practice.

\subsection{The Factors Inhibiting the Partnership Between SMKN 2 Tegal City with the Business and Industry World.}

Several inhibiting factors were found, among others: (1) differences in school orientation and DUDI, where schools focus more on education issues, whereas DUDI is more profit oriented; (2) the limited number of DUDI around the school; (3) DUDI is far from school; (4) DUDI's capacity in accommodating the number of apprentice students; (5) time mismatch in the implementation of school collaboration with DUDI; (6) limited costs required in order to establish cooperation; (7) limited human resources, in this case the number of productive pharmacy teachers is limited.

\subsection{Models of Research Results Offered}

Based on the facts of the research results above. So there are several things that are described in terms of aspects related to activities between schools and the business world and the industrial world, namely:

a) Synchronizing the curriculum, schools and users of the workforce in the business world and the industrial world must work together, especially in terms of learning materials so that those who prepare workers, in this case schools, establish mutually beneficial, give and receive cooperation.

b) Internships or apprenticeships, the business world and the industrial world to provide the widest possible opportunity for students and teachers to practice work or internships so that education actors in schools can experience work in the business world and industrial world so that teachers can prepare their students to be able compete to enter the world of work and students to become accustomed to the work ethic in the business world and the industrial world.

c) Labor recruitment, it is time for business and industrial users to recruit workers from their source (schools) so as to reduce the occurrence of brokering that is detrimental to prospective workers. 
d) Pre-recruitment / recruitment funding, schools need to budget funds for marketing the workforce (their students) because vocational school assignments are not enough to graduate students only but to market their graduates or carry out tracery systems.

e) The model or form of partnership between business and industry and vocational schools in establishing partnerships at SMK Negeri 2 Kota Tegal can be seen in the following diagram:

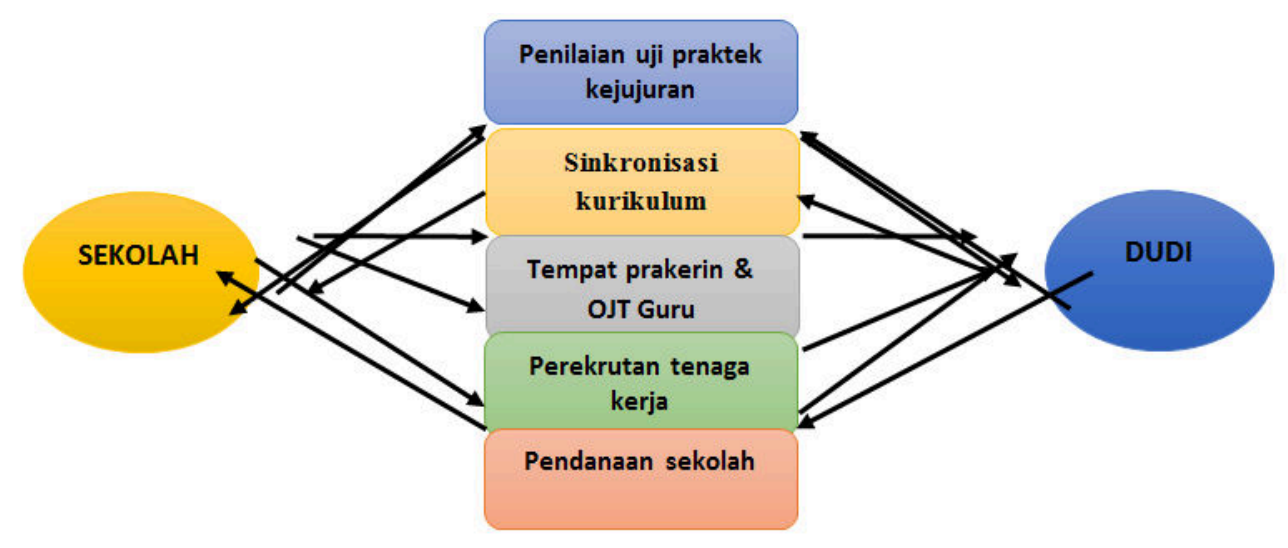

Fig 1. Bentuk Kemitraan SMK dengan DUDI

\section{Conclusions and Suggestions}

\subsection{Conclusion}

The conclusions of this study are as follows: (1) The management of the partnership between the Business World and the Industrial World at SMK Negeri 2 Tegal City includes (a) Planning; (b) Implementation; and (c) Evaluation. (2) Planning for cooperative relations through the school relations program with the business world / industrial world so far implemented at SMK Negeri 2 Tegal City, namely scholarships, internship, training, industrial visits, and alumni recruitment. (3) The implementation of establishing school cooperation includes: The procedure for implementing partnerships with the business world / industry at SMK Negeri 2 Tegal City, as follows: (a) reviewing and adjusting the curriculum with the Business World and the Industrial World; (b) implementation of apprenticeship / PKL for students (Prakerin); (c) implementation of apprenticeship / PKL for teachers; (d) manufacture of traditional preparations / products; (e) implementing vocational competency examinations (UKK). (4) Evaluation in the implementation of school cooperation, among others: (a) Collaboration constraints, namely the lack of enthusiasm of students to work in the business / industrial world, delay in announcing test results, and the Business and Industrial Worlds that pay less attention to students; (b) Indicators of success at SMK Negeri 2 Kota Tegal are quality objectives, vision and mission of the school; and (c) The contribution of the partnership between the Business World and the Industrial World towards the implementation of PBM, including: knowing information about the world of work that is relevant to existing 
study programs in schools, places for sending PKL / Internship students, places for practical learning.

\subsection{Suggestion}

The results of research conducted at SMK Negeri 2 Kota Tegal regarding the implementation of partnerships with DUDI, the researcher provides the following suggestions: (1) Develop and prepare school facilities and infrastructure to equip students to meet field competencies so that students are able to perform apprenticeship when they are working. absorb knowledge at DUDI. (2) The business / industrial world is expected to pay more attention to the interests of students and schools, because students (canakers) are formed by schools who will then be employed in the world of work. (3) The name of the production unit at SMK 2 Tegal City should be more appropriate using the word teaching factory. Because there is basically a place for training students in learning activities.

\section{References}

[1] Abuzar.H. 2011. Building a synergy between SMK and the business world through link and match as a partnership pattern.

[2] Arifin, Zaenal. 2012. Implementation of Partnership-Based Strategic Management in Improving the Quality of Vocational High Schools (Study at SMK Automotive Technology Group in Yogyakarta City). Journal of Educational Administration Vol. XIV No.1 April 2012.

[3] Cooper, D.R., \& Schindler, P.S. 2011. Business research methods. 6th Ed. New York: McGraw- Hill International Edition. p. 100, 149.

[4] Ministry of National Education. (2009). Education Unit Level Curriculum. Jakarta: Curriculum Center, Balitbang Depdiknas.

[5] Hasibuan, H.M., S.P. 2007. Human resource management. Jakarta: PT. Earth Literacy. p. 2, 68, 122.

[6] Ixtiarto, Bambang. \& Sutrisno, Budi. 2016. The Partnership of Vocational High Schools with the Business World and the Industrial World (Study of the Penal Management aspects at SMK Muhammadiyah 2 Wuryantoro, Wonogiri Regency). Journal of Social Science Education, Vol 26, No.1, June 2016.

[7] Kuswana, Sunaryo, wowo, 2013. Basics of Vocational \& Vocational Education. Bandung: Alfabeta.

[8] Lestari, Bekti. \& Pardimin. 2019. Management of School Partnerships with Business and Industry to Improve Competence of Vocational School Graduates. Volume 2 No. 1 June 2019 p ISSN: 2622772 X eISSN: 26223694.

[9] Miles, B.M. \& M.Huberman. 1992. Qualitative data analysis of source books on new methods. Jakarta: UIP. p. 15, 20

[10] Murniati A. R. \& Usman, Nasir. (2009). Implementation of Strategic Management in Empowering Vocational High Schools. Bandung: Citapustaka Media Perintis. Retrieved 27 March 2007 from http://www.udel.edu/chem/white/finalrpt. html.

[11] Neuman, L.W. 2006. Social research methods: quantitative and qualitative approaches. New York: Pearson Inc.

[12] Prastowo, A. 2012. Qualitative research methods in the perspective of research design. Yogyakarta: Ar-ruzzmedia 
[13] Rukmana, Nana. 2006. Strategic Partnering For Educational Management. Bandung: CV. Alfabeta

[14] Setiawan, David Firna. 2016. The Relevance of International Standard Organization (Iso) 9001: 2008 Learning Plans to Learning Plans in Vocational High School (SMK) Process Standards. Equilibria Journal of Education Vol. 1, No. 1, 2016 | 1326. Accessed on 20 May 2018 at 21.50 WIB

[15] Sri Utami. 2010. Vocational High School Partnership with Business and Industry through Industrial Work Practices: Multisite Study at SMK Negeri 3 Malang and SMK Cor Jesu Malang. Thesis. University of Malang.

[16] Sugiyono, 2005, Administrative research methods. Bandung: Alfabeta Publisher.

[17] Suryadi. 2010. "Problems and Alternative Policies for Increasing Education Relevance (Education Relevance Study of UPI Collaboration with Ministry of National Education Balitbang". Http://file.upi.edu/Dirirectory/PROCEEDING/

Seminar Internas.NFE

[18] Syari, D.A. \& Ma'arif, Faqih. 2017. The Partnership Model for the Business World / Industrial World at SMK Pangudi Luhur Muntilan. E-Journal Pend. Civil Engineering and Planning, Vol 5, No 4 (2017). 